\title{
МРНТИ 16.01
}

https://doi.org/10.51889/2020-2.1728-7804.02

\author{
Қосымова $\Gamma^{1}$ \\ ${ }^{1}$ Абай атындавы Қазақ Ұлттық педагогикалық университеті, \\ Алиаты, Қазақстан
}

\section{АУЫЗША СӨЙЛЕУ АКТІСІ - КУРДЕЛІ КҰБЫЛЫС}

\author{
Ан̧датпа
}

Бұл мақалада ауызша сөйлеу актісінің қоғам дамуындағы, жеке тұлғаның танылуындағы маңызды әрекет екендігі сөз болады. Ауызша сөйлеу өнері көпшіліктің алдында орындалатын болғандықтан, оған қойылатын талаптар да жоғары. Шешен сөйлеуге тән анық ойлау, дұрыс пайымдау, ойын ұтымды негіздеу сияқты шарттар - қатынас теориясының басты белгілері. Сондықтан оның ұжымдық сипаты бар, мақсат бірлігі арқылы топтасқан іс-әрекеттер жиынтығы екендігі үнемі басты назарда болу керек. Осы зерттеуде сөйлеу өнерінің шешеннің әлеуметтік МЕНін, интеллектуалдық МЕН-ін, психологиялық МЕН-ін және тағы басқа қабылдаушының тұлғасын құрайтын әртүрлі бірліктерді бағдарға алатындығы айтылады.

Түйін сөздер: ауызша сөйлеу, сөйлеу актісі, интеллектуалдық әрекет, шешен мәдениеті

\author{
Kossymova $G^{1}$ \\ ${ }^{1}$ Kazakh National pedagogical university named after Abay, \\ Almaty, Kazakhstan
}

\section{VERBAL SPEECH ACT IS A COMPLEX PHENOMENON}

\begin{abstract}
This article considers the speech act as an important activity in the development of society and selfknowledge of the individual. Since the art of speaking is performed in front of the public, the requirements are high. Conditions such as clear thinking, correct reasoning, and reasonably substantiating the thoughts are the main signs of a communicative theory. Therefore, we must keep this in the spotlight as a combination of grouped actions through the targeted unity, which have a collective description. This study discusses the importance of the social self, the intellectual self, the psychological self of the speaker of speech art, and other various units that form the personality of a person.
\end{abstract}

Keywords: oral speech, speech act, intellectual activity, oratory

$$
\begin{gathered}
\text { Косьимова Г. } \\
{ }^{1} \text { Казахский Начиональный педагогический университет имени Абая, } \\
\text { Алматы, Казахстан }
\end{gathered}
$$

\section{УСТНОЙ РЕЧЕВОЙ АКТ - СЛОЖНОЕ ЯВЛЕНИЕ}

\section{Аннотацุия}

В этой статье рассматривается речевой акт как важная деятельность в развитии общества и самопознании личности. Поскольку искусство устной речи совершается перед публикой, то и требования ставятся высокие. Такие условия как четкое мышление, правильное рассуждение, разумно обосновывать свои мысли - являются главными признаки коммуникативной теории. Поэтому мы должны держать это в центре внимания как совокупность сгруппированных действий с помощью целевого единства, которые обладают коллективным описанием. В этом исследовании рассказывается о важности социального Я, интеллектуального Я, психологического Я оратора речевого искусства и другие различные единицы формирующие личность человека.

Ключевые слова: устная речь, речевой акт, интеллектуальная деятельность, ораторское искусство 
Кіріспе. Біздің қазіргі қоғамымызда шешендік өнердің көрінетін жерлері әлдеқайда кеңіді: ол саяси-әлеуметтік өміріміздің барлық саласында идеологиялық күрестің, тәрбие мен оқу-ағартудың, заң мен ғылымның, қоғамды басқарудың ең бір пәрменді құралына айналды. Сонымен қатар “"шешендік -ауызша жүргізілетін үгіт-насихат жұмыстарының бірден-бір құралы. Жиналыс, конференция, съезд, симпозиум, семинар, диспуттар да шешендік өнер өте-мөте қажет. Бұл күнде шешендікті радио мен телевизия да көрсетеді, өйткені бұларға жазба тілмен қатар ауызша сөйлеудің үлгісі ортақ" [1,14].

Шешендік өнер ғалым Р.Сыздықтың негіздеуінің арқасында сөйлеу өнері ретінде тілдің зерттеу нысанына айналды. Бұрын жұртшылықтың арасында фольклордың бір жанры ретінде кең таралған, талай зерттеулерге материал болған шешендік сөзді сөйлеу өнерінің туындысы ретінде қарамасақ, шешендіктің соңғы дәуірде дамымай тоқтап қалған сала болып қалар сөзсіз еді. Осы тұрғыдан алғанда Р.Сыздық айтқан мына пікір өте маңызды болды: “Шындығында өте ерте замандардан бері өмір сүріп, біздің дәуірімізге дейін жетіп, бүгінгі мәдени-рухани өмірімізден орын алып келе жатқан шешен сөйлеу дәстүрі (құбылысы, актісі) бар. Және ауызша сөйлеудің аясы ұлғайған сайын, шешен сөйлеудің де қажеттілігі артып отыр" [2,42].

Әдістеме. Осы пікірдің жарық көруінен бастап-ақ, біріншіден, ауызша сөйлеу мәдениеті дербес зерттеу тақырыбына айналып, қарым-қатынас мәдениетінің нысанына айналды. Екіншіден, ауызша сөйлеу- акт ретінде назарға ілікті. “Акт” деген терминнің қолданысы сөйлеу дегеннің әрекет екенін ұғындырды. Сөйлеу- адам әрекеттерінің жай ғана бір түрі ғана емес, ол әрекеттердің ішіндегі адам үшін, қоғам үшін ең маңыздысы. Барлық әрекет- белгілі бір нәтижеге жету үшін бағытталатын, ұжымдық сипаты бар, мақсат бірлігі арқылы топтасқан іс-әрекеттер жиынтығы [3,50-54]. Адам әрекеттерінің бәріне қозғаушы күш болатын, мақсаттың орындалу тетігіне айналатын сөйлеу актісіөте күрделі құбылыс. Оның күрделілігі- адамға ғана тән үш негізден -сөйлеу, есту, ұғыну деген үш бөлімнен тұратындығында. Жоғарыдағы пікірден түйетін үшінші мәселе: “сөйлеу” тілдің өмір сүру формасы дегенді нақтылайды. Яғни тілді қатынас әрекетінде, өз ойын басқаларға білдіру, басқаның ойын білу мақсатында қолдану деген сөз. Тіл “біздің өмір сүру салтымызды танытатын тәжірибелік дағдыларымыз бен идеяларымыздың әлеуметтік жинақтық қоры” [4,185] мәдениеттен тыс өмір сүрмейді. Ойлауды жүзеге асыру формасы ретінде, бастысы қарым-қатынас құралы ретінде тіл мәдениетпен бірдей деңгейде тұра алады [5,48]. Бұл мақсат сөйлеу әрекетіне қатысты тек тілдік нормаларды дұрыс, дәл, айқындылықпен қолданғанда ғана емес, шешендік нормаларын біліп, ой айқындылығы, логикалық жүйе сақталғанда ғана жүзеге асады. Осыдан шешендік өнердің қоғамның барлық саласында қажетті қарым-қатынас құралы ретіндегі қоғамдық мәні таныла түседі. “Аса мәртебелі қарым-қатынас адамзатқа билік жүргізіп, оның өмірін, дамуын, іс- әрекетін, жалпы танымы мен жаратылыстың бір бөлшегі ретінде өзін-өзі тануын басқарып отыр" [6, 13].

Нәтижелер. Бұдан шешендік өнерді оның әлеуметтік мәні мен қоғамдық сипатына қарай антропоөзекті бағытқа қарай зерттеу қажеттілігі туындайды. Адами құндылықтарға назар аударуды қажет ететін бүгінгі қоғамда әлемдік дүниетанымда және қоғамды демократияландыруда зор үлес атқарған риториканың жалпыға ортақ ережелерін нақтылап еске түсіру, адам мінез-құлқын қалыптастыруда жоғарғы мораль үлгісі ретінде танылған шешендік сөздің танымдық-тәрбиелік мәнін анықтау өзекті мәселе болып табылады.

Антропоөзекті зерттеудің мақсаты не болмақ: риториканың -сөйлеу өнерінің ең жоғарғы түрі екендігі және оның өркениетті қоғамға тән екендігін таныту; адамзаттың басынан кешірген барлық қоғамында риториканың атқарған қызметі қоғам мүшелерінің мінез-құлқын тәрбиелеу болғандығын дәлелдеу; адамдардың жүрегіне жол табатын сөздің шынайылығы, ашықтығы, анықтығы, мәнерлілігі, қызуғушылықты білдіруі- риториканың басқа сөйлеу түрлерінен ерекшелігі екендігін айқындау; риториканың қызметі-қоғамды басқару, мораль қалыптастыру болатындығын түсіндіру; бүгінгі қоғамдағы шешен бейнесін анықтау; тұлғатануда идея мен мәнердің бірлігін көрсету; адамның қоғамдағы орнын сезіне білуі-шешендікке апарар жол екендігін түсіндіру; қарым-қатынаста әр адамның бойындағы ұшқынды (искраны) таба білудің қажеттігін дәлелдеу; басқаларды тыңдай білушілік -пікірлесудің ұтымды тәсілі екендігін білгізу; сөз өнері ғылымының міндеті-жауапты әрі іскер, отаншыл азаматтарды тәрбиелеу екендігін айқындау.

Талқылау. Р.Сыздықтың шешендік өнер туралы зерттеуінің тағы бір маңызы мынада болатын: сөз мәдениеті және оған қойылатын талаптар тілдік қарым-қатынастың нормалары ретінде қаралып, риториканың тарихи мәні жоғалып, оған деген қызуғушылық төмендеген сәтте, риторика ғылымының қарастыратын мәселелерін анықтаудың және оның қоғамды гуманизациялаудағы рөлінің 
жоғары екендігін танытуында. Ғалым зерттеуіне негіз болған шешендік сөйлеу өнерінің қазіргі қоғамдағы түрлері, қолданылатын орындары, олардың өзіндік нормалары, сапалық белгілері, қоғамдық-тарихи аспектілері тек тіл білімі үшін ғана емес, қазіргі шешен бейнесін танып білу үшін де маңызды. Ғалым: “Шешендік өнер тіл мәдениетін көтеретін шарттардың бірінен саналады,-дей келіп,-біздіңше, “шешендік сөз” деген терминді шешендік өнердің іс жүзіне асқан нәтижесін атауға қалдыру керек, яғни фольклор мұрасының бір жанрын және қазіргі кезде шешен айтылған сөзді осылайша атау керек те, ал шешендік өнердің, сөзге шеберліктің өзін сәл болса да өзгеше атау қажет. Бұл ұғымға "шешендік” деген абстракт есімді теліп, “ол-шешен сөйлеу” деген актінің атауы болса дейміз”,- деген еді [2,39-40]. Міне, содан бері шешендік атауы бір ғылым саласының туып, қалыптасуына тірек сөз болды. Ол қоғамның барлық салаларында адамды танытудың және қоғамды ізгілендірудің жолы ретінде қарастырылатын тірек ойдың тууына себепші болды.

Р.Сыздықтың “Қазақ әдеби тілінің ауызша түрі” деген кітапқа енген зерттеуінде орын алған тірек ойлардың бірі- монологтік шешендік сөйлеу түрінің сипаты. Оған дейінгі және кейінгі біраз еңбектерде шешендік сөз таласқа түскен дискурстық сипаты бар, тілдік қарым-қатынастағы сөз жарысы ретінде қарастырылды. Ғалым қазіргі шешендік сөздің түрлерін жіктеп, әрқайсысына тән белгілерді анықтағанда зерттеу материалы ретінде монологтік сөйлеу үлгілерін тілге тиек етті. Монологтік сөзде дискурсқа қарағанда шешен бейнесі айқынырақ танылады. Оның себебі мынада: тілдік қарым-қатынастағы сөз мәдениеті шешеннің “МЕН-мен” тығыз байланысты. Әрбір ойдың иесі сөйлейтін сөзін өз танымына сәйкес құрып, өзіне тән әлемін жасайды. Адам айналасындағы шындыққа бейімделіп, өзін қоршаған әлемді өз санасында қалыптасқан ұғым-түсінікпен қабылдайды, сөйтіп өз көзқарасын қалыптастырады. Қоршаған ортаға өзіндік көзқарасын танытатын шешеннің ішкі әлемі әсіресе монологтік сөйлеуде айқынырақ көрінеді. Шешеннің ішкі әлемінен туындаған мәтін автордың “МЕНІН” тануға мүмкіндік береді. Кез келген мәтіннің негізгі мақсаты- тілдік жағдаяттарда пікіралмасуды іске асыру, тыңдарман не оқырманның жан дүниесіне әсер етіп, оны “ояту”, “реакция туғызу”. Бұл әрекет шешеннің ішкі таным дүниесінің дәрежесіне, «сөз құдіретіне» байланысты болады. Адамның түрлі формада қарым-қатынасқа түсе алу қабілеті оның сана-сезім деңгейіне байланысты. Әрбір шешен тілдік тұлға болып саналады. Тілдік тұлға деп танылуы үшін сөйлеген сөздердің негізінде жатқан құндылықтарды танып білуі керек.

Шешен өзінің коммуникативтік діттеміне сәйкес әлеуметтік МЕН-ін, интеллектуалдық МЕН-ін, психологиялық МЕН-ін және тағы басқа қабылдаушының тұлғасын құрайтын әртүрлі бірліктерді бағдарға алады. Шешеннің алдына қойған мақсатына жетуі, оның коммуникативтік діттемін тыңдаушының дұрыс зерделеуі, ой елегінен дұрыс өткізуі тілдесудің ойдағыдай өтуінің негізгі шарты болып табылады. Тілдік қатынасқа түскен сөз иелері - шешен мен тыңдарман (оқырман) арасындағы тілдік қатынас олардың әлеуметтік мәртебесі, жас ерекшеліктері, жыныс айырмашылығы, танысбейтаныстығы немесе тілдік қатынастың ресми-бейресмилігіне байланысты болып қана қоймайды, сөз құрылымымен, сөз иелерінің танымдық санасымен, яғни білім, түсіну, түйсіну, ойлау, пайымдау, ой қорыту қабілеттерімен де байланысты.

Монологтік сөз-аса күрделі коммуникативтік құрылым. Сөз айтылғанға (жазылғанға) дейін де шешеннің айтсам, жазсам деген діттемі, нені айтсам, қалай айтсам, кімге айтсам деген мақсаты, қызығушылығы болады. Осы діттемі сөзді қабылдаушының белсенді іс-әрекетін, назар аудару, ден қою, түсіну, қабылдау амалдарын туғызуы керек. Қабылдаушының түсіну амалы бірінен кейін бірі айтылған сөз тізбектерін ой елегінен өткізуден басталып, шешеннің нені айтпақ болғанын ұғынумен, ой қорытындысын шығарумен аяқталады. “Шешеннің сөзі арқылы берілетін ойы мен сезімі тыңдарманға белгілі бір жолдау сияқты түрткі беруі керек. Тыңдаушы оны сезбесе, айтылған сөз оның жүрегіне жетпесе, мұндай шешеннің сөзі сахарадағы құмға сіңген сөзбен бірдей болады” деген Дейл Карнеги шешен сөзінің аса күрделі коммуникативтік құрылым екенін көрсетеді [7,305].

Осы жағдайларға сәйкес, монологтік шешендік сөйлеуде қолданылатын ережелер бар.Әр адамның өзіндік сөйлеу мәнеріне сәйкес көңіл күйін, ішкі толғаныстарын, айтып тұрған хабарға көзқарасын білдіретін алуан түрлі мағыналық реңктер тек сөйлеу әрекетінде ғана болады. Сол себепті сөйлеуде ешкімге ұқсамайтын даралықтың болуы шешен тұлғасын тануға мүмкіндік береді. Маңызды сөздерге акцент қойып, ал қалғандарын соларға бағындыру қажеттілігінің ескерілуі шешеннің шеберлігіне байланысты .

Дауыс ырғағын ауыстырып отыру және сөйлеу барысында кідіріс жасау, сондай-ақ сөйлеудің темпін өзгертіп отыру маңызды. Мәтіннің идеясын білдіретін басты сөйлемнің алдында және кейін кідіріс жасау жетістікке жеткізеді. 
Көптеген ғалымдардың зерттеулерінің қорытындысы бойынша, жетістіктердегі басты рөлді атқаратын нәрсе - ол жоғарғы интеллект емес, адамның тұлғасы және оның көзқарасы. Әрине, бұл қағида шешенге тікелей қатысты екені даусыз. Жақсы дайындықты санамағанда, шешен тұлғасының сәттілікке жеткізуде маңызы ерекше. Элберт Хаббард айтқан екен: “Шешендік өнерде мәнер сөзден де маңызды. Дәл айтқанда, мәнер және идея. Бірақ тұлға - бұл көзге көрінбейтін, қолға ілінбейтін, талдауға келмейтін шегіргүлдің иісі сияқты белгісіз нәрсе. Ол адам бойындағы барлық қасиеттердің: физикалық, рухани, интеллектуалдық, психологиялық, сондай-ақ талғамдарының, қабілетерінің темпераментінің, ойлау дағдысының, қуатының, тәжірибесінің, білім деңгейінің және жалпы өмірінің жиынтығы.

Егер сөйлеуде тұлғаңыздың қабілеттерін бар қуатымен жұмсағыңыз келсе, онда тыңдаушылар алдына жақсылап демалып, тамақтанып, сөйлейтін сөзді алдын-ала асықпай жақсылап жүйелеп барып шығуыңыз керек. Басқа жағдайда сіздің дауысыңыз, энергетикаңыз, адамдарға магниттік ықпалыңыз бәсеңдейді де, сөзіңіз сәтсіз шығуы әбден ықтимал”.

Шешендік өнер теориясында шешен тұлғасын негіздеу ісі басталғанымен, әлі де толыққанды зерттелген жоқ. Шешендік өнер теориясын жасаған әлемге әйгілі ғалымдардың еңбектерінде көрініс тапқан төмендегі көптеген мәселелер қазақ тіл білімінде әлі де зерттеуді қажет етеді.

Шешеннің дауыс ырғағы, күші шешендік сөздің мазмұнын тыңдаушылардың дұрыс түсініп, қабылдауына әсер етеді. Өте тез қарқынмен сөйлеу анықтықты азайтады; баяу, баппен сөйлеу анықтықты күшейтеді. Қатты дауыспен сөйлеу айқындылықты өсіреді; жәй, бәсең дауыспен сөйлеу айқындылықты кемітеді. Үзіп-үзіп сөйлеу көңіл бөлуді әлсіретеді, үзіліссіз сөйлеу көңіл бөлуді күшейтеді. Тыңдаушылар жиналған орынның акустикалық мүмкіншілігінен тыс дауыс қаттылығы немесе мейлінше ақырын дауыс айқындылықты азайтады, бірақ шектен тыс қатты дауыс көңіл бөлуді әлсіретсе, баяу, ақырын сөйлеу көңіл бөлуды күшейтеді. Осылайша шешен дауыс күшінің сапасын сөйлеудің түсініктілігіне қол жеткізу мақсатында өзгертіп пайдаланып отырады. Шешен сөйлеу қарқынын өзгерту нәтижесінде тыңдаушыларға әсер етеді [1, 244].

Р.Сыздықтың бастауымен жалғасын тауып келе жатқан зерттеулерде орын алған ой-тұжырымдар мыналар:

-шешендік өнер-тек әдемі сөйлеу ғана емес, адамдарды өзін-өзі бағалауға үйрететін ғылым;

-шешендік өнер- тарихи құбылыс қана емес, қоғамдық құбылыс;

-шешендік өнер- қоғамды ізгілендірудің бірден бір жолы;

-шешен тұлғасы-этика мен мәнердің, білім мен ақылдың тоғысуы;

-шешендік өнер- адамдарды сендірудің, ізгі істерге жетелеудің, адамдар арасында жылы қарымқатынастың орнауының кепілі;

-шешендік өнер-іскер, ұғымтал, алдын болжағыш, жауапты, интеллектуалды тұлға қалыптастыратын ғылым саласы.

Корытынды. Шешендік өнерге байланысты жоғарыда айтылған тұжырымдар сөйлеуді өнер етіп қабылдап, оны әлеуметтік мәні мен қоғамдық сипатына қарай антропоөзекті бағытқа қарай зерттеу қажеттілігі туындайды. Сөйлеу актісі көп қырлы құбылыс болғандықтан, оның зерттеу аясы кең, болашақта зерттелу мүмкіндіктері мол.

Пайдаланылван ддебиеттер тізімі:

1 Қосымова Г. Шешендік өнердің негіздері. - Алматы: 2015. -258 б.-кітап

2 Сыздықова Р. Шешендік сөз/ /Қазақ ддеби тілінің ауызиа түрі. -Алматы: 1987. - $26-112$ б.

3 Абдулжанова 3. (2013). Ауызша тілдегі тілдік бірліктердің қатыссылдық сипаты . Әл -Фараби атындавы Қазақ Ұлттық университеті, Алматы: Қазақстан. -Диссертация.

4 Сепир Э. Язык. Введение в изучение речи// Избранные труды по языкознанию и культурологиию. - Москва: 1993. - 656 с. - книга

5 Бромлей Ю.В. Этнос и этнография. М: 1975. - 284 с. -книга

6 Светлана Тер-Минасова. Тіл және мәдениетаральқ коммуникация. -Астана: 2018. -317 с.

7 Карнеги Д. Как завоевывать друзей и оказывать влияние на людей. Алмать: 1992. - 496 с.

References:

1. Qosymova G. Şeşendık önerdiñ negızdert. -Almaty: 2015. -258 b.-kıtap

2. Syzdyqova R. Şeşendık söz/ /Qazaq ädebi tılınıñ auyzşa türı. -Almaty: 1987. - 26-112 b.

3. Abduljanova Z. (2013). Auyzşa tıldegl tıldık bırlıkterdıñ qatysymdyq sipaty . Äl-Farabi atyndăgy Qazaq Ūlttyq universitetı, Almaty: Qazaqstan. -Disertasia. 
4. Sepir E. İazyk. Vvedenie v izuchenie rechi// İzbrannye trudy po iazykoznaniu i külturologiiu. Moskva: 1993. - 656 s. - kniga

5. Bromlei Iu.V. Etnos i etnografia. M: 1975. - 284 s. -kniga

6. Svetlana Ter-Minasova. Tul jäne mädenietaralyq komunikasia. -Astana: 2018. -317 s.

7. Karnegi D. Kak zavoevyvät druzei i okazyvät vlianie na lüdei. Almaty:1992. - 496 s.

МРНТИ 16.21.41

https://doi.org/10.51889/2020-2.1728-7804.03

Құрманбайұлы Ш., ${ }^{1}$ Әділов M. ${ }^{2}$

1,2 Абай атындагы Қазақ ұлттық педагогикалық университеті, Алматы, Қазақстан

\title{
АБАЙ ШЫҒАРМАЛАРЫНДАҒЫ «ТҰҒЫН» ЖҰРНАҚТЫ ЕСІМШЕНІҢ ҚОЛДАНЫСЫ
}

\begin{abstract}
Аңдатпа
Мақалада ертеректе кеңінен жұмсалып, қазіргі күні тек белгілі өңірлерде ғана айтылатын бірақ көркем әдеби шығармаларда әлі де қолданылатын «тұғын» формасы зерттеліп қарастырылды.ХІХ ғасырда қазақ жазба тілінде актив қолданылған«тұғынды» қазақтың ұлы ақыны Абай өз шығармаларында пайдаланған. Оны хакім Абайдың қалай әрі қанша рет қолданғанымысалдармен көрсетілді. Түркі ескерткіштері мен тілдерінен алған талдаулар негізінде «тұғын» формасын шағатайшаның элементіәрі говорлық ерекшелік емес екендігі дәлелденді. Ақын тіліндегі тұzын қазақ тілінде жыраулар дәуірінен бері қолданылып келе жатқан дәстүр жалғастығының көрінісі болғандығы айтылды. Сондай-ақ, есімшенің бұл түрінің қазіргі поэзия тілдегі қолданысына да назар аудару мақсатында М.Жұмабаев, Қ.Аманжолов, М.Мақатаев, Ж.Нәжімеденов сияқты ХХ ғасырдың көрнекті ақындары тіліндегі қолданыстарына тоқталып, салыстырмалы талдау жасалды.
\end{abstract}

Түйін сөздер: Абай, Абай шығармалары, тұғын қосымшасы

$$
\begin{gathered}
\text { Kurmanbaiuly S., }{ }^{1} \text { Adilov } M .{ }^{2} \\
{ }^{1,2} \text { Kazakh National Pedagogical University after Abay, } \\
\text { Kazakhstan, Almaty }
\end{gathered}
$$

\section{THE USE OF THE SACRAMENT "THUGIN" IN THE WORKS OF ABAI}

\section{Abstract}

The article analyzes the process of transformation of the participle "tyn" which is actively used in the modern literary language. In particular, we are talking about the dialectical character of the ending "tugyn" used earlier in the Kazakh language, and is currently used only in some regions of Kazakhstan. The grammatical form "tugin" occurs frequently in the writings and texts of XIX beginning of XX centuries. The great Kazakh poet Abay actively used this form in his works. Using examples, we analyze the frequency of use in Abay's works. Based on the analysis of Turkic monuments and languages, we will try to prove that the suffix "tugyn" is not an element of the Chagatai language and a dialect exception, that this form is native Kazakh on the bright examples of akyn-zhyrau, poets and researchers of Kazakh literature. Also, in order to draw attention to the use of this type of participle in the modern language of poetry, a brief comparative analysis of the works of outstanding poets of the twentieth century, such as M.Zhumabayev, K.Amanzholov, M.Makataev and Zh. Nazhimedenov.

Keywords: Abay, Abay communion,"tugin"participle 